Menoufia J. Soil Sci., Vol. 6 November (2021): 299 - 320 https://mjss.journals.ekb.eg/

\title{
OPTIMIZING USE OF ENHANCED EFFICIENCY N FERTILIZERS TO IMPROVE WHEAT- MAIZE CROPPING SEQUENCE UNDER ALLUVIAL SOILS
}

\author{
Eman H. Abd El-Azeiz, Riham M.N. Faiyad and Enas E. Yousif \\ Soil Fertility and Plant Nutrition Research Department; Soils, Water and Environment \\ Research Institute (SWERI); Agricultural Research Center (ARC), Giza, Egypt
}

Received: Oct. 23, 2021

Accepted: Nov. 6, 2021

\begin{abstract}
Collectively, the challenges aim to accelerate the development of innovative fertilizer product technologies and to increase the use of existing enhanced efficiency fertilizers sources (EEFS) like slow release fertilizers (SRF) as an example for increasing crop yields and reducing environmental impacts to air, land and water. Two field experiments were carried out at Experimental Farm of Tag El-Ezz, Agricultural Research Station $\left(30^{\circ} 59^{\prime} \mathrm{N}\right.$ latitude, $31^{\circ} 58^{\prime} \mathrm{E}$ longitude'), Agriculture Research Center (ARC), Dakahlia Governorate, Egypt. Completely randomized blocks design (CRBD) with three replicates was used during the two winter and summer successive growing seasons $20 r \cdot / 21$ and 2021 to study the effect of three different slow release nitrogen fertilizer (SRNF) sources 1- sulfur coated urea (SCU), 2- urea formaldehyde (UF) and 3cement coated urea $(\mathrm{CCU})$ with different fertilization rates $(100,125$ and $150 \%$ from the recommended dose) comparing with conventional urea (CU) under recommended fertilization rate for wheat and corn crops respectively (75 and $120 \mathrm{~kg} \mathrm{~N} \mathrm{fed}^{-1}$ ) on growth, yield and its components of wheat (Triticum aestavium L.) cv. Misr1 during the winter season. As well as studying the residual effect of (SRNFs) with half additional application does of conventional urea to each plot on maize (Zea mays L.) var. (Tri Cross 360) growth, yield and its components. Available soil $N$ in the experimental plots was determined during the growing seasons along the two experiments.

The obtained results indicated the ability to use new age technologies as enhanced efficiency fertilizers (EEFS) like slow release fertilizers (SRFs) to sustain crops yield and maintain environment quality.
\end{abstract}

SRNFs applications gave the highest values of vegetative growth, yield and its components of wheat plant compared to conventional urea. Raising rate of $\mathbf{N}$ fertilizer caused an increase in all studied parameters.

SCU using at $100 \%$ fertilization rate was the superior SRNF using at the same rate where it increased ChIIC a+b and BY by 31.23 and $19.95 \%$, respectively, as well as it gave the highest grain nutrients concentration and protein content by $2.35 \%$ for $\mathrm{N} ; \mathbf{0 . 2 8 9 \%}$ for $\mathrm{P}$; $1.38 \%$ for $\mathrm{K}$ and $13.51 \%$ for protein comparing with $\mathrm{CU}$ using at $100 \%$ fertilization rate.

The highest residual $\mathrm{N}\left(\mathrm{mg} \mathrm{kg}^{-1}\right)$ in the soil after wheat harvesting was recorded with cement coated urea (CCU) and the same trend continuous to maize post harvesting. Thus the residual of CCU using at $100 \%$ fertilization rate $+50 \%$ CU increased maize ChlIC $a+b$ and $B Y$ by $36.40 \%$ and $7.27 \%$, respectively as well as it gave the highest values of maize grain content from $N(2.09 \%), P(0.134 \%), K(1.46 \%)$ and oil content $(5.20 \%)$ comparing with $\mathrm{CU}$ using at $100 \%$ fertilization rate.

Economically, we advised farmer using SCU at $100 \%$ fertilization rate for one crop and using CCU at $100 \%+50 \% \mathrm{CU}$ recommended fertilization rates for cropping sequence.

Key words: Slow release fertilizers, residual effect, cropping sequence, wheat and maize. 


\section{INTRODUCTION}

The most reliable and effective way to make the availability of nutrients coincide with plant requirements is by controlling their release into the soil solution. Slow release fertilizers (SRFs) are considered as novel and revolutionary approaches in the field of fertilizer synthesis. SRFs are seen as economical and environmentfriendly alternative to chemical fertilizers.

The most common nitrogen fertilizer product used all over the world is urea $\left(\mathrm{CO}_{2} \mathrm{NH}_{2}\right)$. It has concentrated nitrogen content $(46.5 \%)$ and also with a low cost (Glibert et al., 2006). Urea dissolved in soil water just applied through a short time ranging between minutes to hours releasing ammonia $\left(\mathrm{NH}^{4+}\right)$ and bicarbonate $\left(\mathrm{HCO}^{3-}\right)$, it losses by leaching, volatilization and decomposition causing environmental pollution (Al-Kanani et al., 1991).

Slow release fertilizers (SRFs) were produced to avoid or at least reduce losses of conventional fertilizers and also enhance the fertilizers efficiency. It can be defined as a fertilizer that supply nutrient to plants for a long time than conventional urea fertilizer (Trenkel, 2010). Slow release fertilizers (SRFs) are made of soluble fertilizers coated with inorganic materials such as sulfur or mineral-based coatings and fertilizers coated with an organic polymer that control water penetration and thus limit dissolution rate of nutrient which make it controls releasing of nutrient as plant need (Sartain et al., 2004).

Urea Formaldehyde (UF $38 \% \mathrm{~N}$ ) is the first developed group of slow release nitrogen fertilizers, it is formed by a reaction between formaldehyde and excess of urea under controlled conditions i.e. $\mathrm{pH}$, temperature, mole proportion, reaction time, etc. (Watson,
2013). It's a good slow release nitrogen fertilizer (SRNF) for most crops where it has a low solubility. On the other hand, it's used widely in warmer climates as in the Mediterranean region where it's more effective in case of higher temperatures than cold one (Trenkel, 2010).

Sulfur coated urea (SCU $30-40 \% \mathrm{~N}$ and approximately $20 \%$ S) is produced through coating hot urea by molten sulfur which considered as a cheap cost coating. $\mathrm{N}$ releasing from $\mathrm{SCU}$ particles is positively affected by the thickness and quality of the coating (Shiva et al., 2016).

As well as plant growth required micronutrients in trace amounts. Cement is the less expensive coating example that release micronutrient as silicon, aluminum and iron where it contains 78 $\% \mathrm{CaCO}_{3}, 14 \% \mathrm{SiO}_{2}, 2.5 \% \mathrm{Al}_{2} \mathrm{O}_{3}$ and 1.75 $\% \mathrm{Fe}_{2} \mathrm{O}_{3}$. (Muller, 1974 and El-Ghamry et al., 2016).

Crop sequences are important for studying the productivity of a long-term rotation. Sequenced crops may enhance soil quality and crop production. (Hamd Alla et al., 2015).

Wheat (Triticum aestavium L.) as well as corn (Zea mays $L$.) crops are required high amounts of nutrients especially $N$. Sequence of cereals in the same field in two successive growing seasons affects negatively on the soil fertility leading to a reduction in crops yield.

So that, this research was made to find out the performance of slow release fertilizers (SRFs) as enhanced efficiency fertilizers sources (EEFS). Studying effect of sources and rates of three SRNF forms on wheat and corn cropping sequence productivity as well as their residual effect on soil nitrogen content for the second growing season under alluvial soils condition. 


\section{MATERIALS AND METHODS}

\section{Experimental Field Location and Cropping Sequence}

Two field experiments were conducted during consecutive seasons at the farm of Tag El-Ezz, Agricultural Research Station, Agricultural Research Center (ARC), Dakahlia governorate, Egypt, (located at $30^{\circ} 59^{\prime} \mathrm{N}$ latitude, $31^{\circ} 58^{\prime} \mathrm{E}$ longitude') during the winter (wheat) and summer (maize) 20r./21 and 202) growing seasons to study the effect of different nitrogen fertilizer forms as enhanced efficiency fertilizers sources
(EEFS) and rates on growth, yield and nutrients uptake of wheat, as well as the residual effect on the soil then on maize growth, yield and nutrients uptake through wheat- maize cropping sequence.

Random disturbed soil samples from the surface of the soil $(0-30 \mathrm{~cm})$ were collected before wheat planting. Some physical and chemical properties of the experimental soil were determined according to Page et al. (1982) and Klute (1986) as shown in Table 1.

Table 1. Physical and chemical soil properties of the experimental site at Tag El-Ezz during $r \cdot r \cdot \mid r \cdot r /$ growing seasons.

\begin{tabular}{|c|c|}
\hline \multicolumn{2}{|c|}{ Soil Characteristics } \\
\hline \multicolumn{2}{|c|}{ I. Physical properties: } \\
\hline \multicolumn{2}{|c|}{ Particle size distribution } \\
\hline Sand & 19.50 \\
\hline Silt & 38.09 \\
\hline Clay & 42.41 \\
\hline Soil Texture Class & Clay \\
\hline \multicolumn{2}{|c|}{ II. Chemical properties: } \\
\hline $\mathrm{pH},[1: 2.5$ soil suspension] & 8.00 \\
\hline EC, [soil past, dS m-1] & 2.97 \\
\hline \multicolumn{2}{|c|}{ Soluble cations, meq $100 \mathrm{~g} \mathrm{soil}^{-1}$ ) } \\
\hline $\mathrm{Ca}^{2+}$ & 5.61 \\
\hline $\mathrm{Mg}^{2+}$ & 5.30 \\
\hline $\mathrm{Na}^{+}$ & 16.21 \\
\hline $\mathrm{K}^{+}$ & 2.62 \\
\hline \multicolumn{2}{|c|}{ Soluble anions, meq $100 \mathrm{~g} \mathrm{soil}^{-1}$ ) } \\
\hline $\mathrm{CO}_{3}{ }^{2-}$ & - \\
\hline $\mathrm{HCO}_{3}^{-}$ & 1.21 \\
\hline $\mathrm{Cl}^{-}$ & 13.11 \\
\hline $\mathrm{SO}_{4}^{2-}$ & 15.42 \\
\hline $\mathrm{CaCO}_{3}, \%$ & 4.79 \\
\hline OM, \% & 1.42 \\
\hline \multicolumn{2}{|c|}{ III. Nutritional properties: } \\
\hline $\mathrm{N}, \mathrm{mg} \mathrm{kg}^{-1}$ & 50.10 \\
\hline $\mathrm{P}, \mathrm{mg} \mathrm{kg}^{-1}$ & 8.96 \\
\hline $\mathrm{K}, \mathrm{mg} \mathrm{kg}^{-1}$ & 242.08 \\
\hline
\end{tabular}


Eman H. Abd El-Azeiz, et al.,

\section{Slow Release Nitrogen Fertilizers (SRNFs)}

Table 2 shows analysis of the samples from different nitrogen fertilizers sources according to methods described by Salman, (1988) and Vashishtha et al. (2010).

\section{Experimental Treatments Statistical Design.}

The experiment was comprised of ten treatments including three slow release $\mathbf{N}$ fertilizers applied with three fertilization rates in addition to conventional urea with one application rate (recommended). Total ten treatments were distributed in a randomized complete blocks design with three replicates. Fertilizers were added to wheat plant at rates of $100 \%, 125 \%$ and $150 \%$ from recommended rate $(75 \mathrm{kgN}$ $\mathrm{fed}^{-1}$ ) in forms of sulfur coated urea (SCU, $41 \% \mathrm{~N}$ ), urea formaldehyde (UF, $38.3 \% \mathrm{~N}$ ) and cement coated urea (CCU, 37.2\% N) comparing with conventional urea $(46.5 \%$ $\mathrm{N})$ at recommended dose. Slow release fertilizers were applied at sowing, while urea was applied in three splits after 0, 25 and $\mathbf{4 5}$ days after sowing. Maize received $50 \% \mathrm{~N}$ from recommended dose $(120 \mathrm{~kg}$ $\mathrm{N}$ fed $^{-1}$ ) as conventional urea. $\mathrm{P}$ and $\mathrm{K}$ fertilizers were applied as recommended by the Ministry of Agriculture and land Reclamation (MARS).

\section{Cultivation Practices:}

Seeds of wheat (Triticum aestavium L.) Cv. (Misr1) and of maize (Zea mays $L$ ) cv. (Tri Cross 360) were obtained from Field Crops Research Institutes (FCRI), MARS, Egypt . Wheat seeds were sown in 17 November 2020 and the harvest was in 28 April 2021. On the same field, maize seeds were sown in 3 Jun 2021 and the harvest was in 27 September 2021.

\section{Plant Growth Stages Parameter Data:}

\section{1-Vegitateve Growth Parameters and Chemical Constituents.}

Plant samples of each crop were collected from each plot at maximum vegetative growth stage for measurement of some growth parameters (shoot height (ShH), cm; shoot fresh weight (ShFW), g and shoot dry weight (ShDW), g as well as chlorophyll $a$ and $b$ ( $\mathrm{mg} \mathrm{g}^{-1}$ fresh weight of leaf) were determined using a method described by Nayek et al. (2014). Total $\mathbf{N}, \mathrm{P}$ and $\mathrm{K}$ content were determined according to the methods described by Buresh et al. (1982) and Chapman and Pratt (1961), respectively.

Table 2. Analysis of the different nitrogen fertilizers sources used during the winter (wheat) 2020/2021 season.

\begin{tabular}{|c|c|c|c|c|c|}
\hline \multirow[b]{2}{*}{$\mathbf{N}$ fertilizers } & \multirow{2}{*}{$\begin{array}{l}\text { Coating } \\
\text { material }\end{array}$} & \multirow[b]{2}{*}{ Color } & \multicolumn{2}{|c|}{$\%$} & \multirow{2}{*}{$\begin{array}{c}\text { Dissolution } \\
\text { rate, } \\
\text { minute.gm }\end{array}$} \\
\hline & & & $\begin{array}{c}\mathbf{N} \\
\text { concentration }\end{array}$ & \begin{tabular}{|c|} 
coating \\
Percentage
\end{tabular} & \\
\hline $\begin{array}{c}\text { Conventional Urea } \\
\text { (CU) }\end{array}$ & - & White & 46.5 & - & 0.118 \\
\hline $\begin{array}{l}\text { Sulfur coated urea } \\
\text { (SCU) }\end{array}$ & Sulfur & Yellow & 41.0 & 10.3 & 0.252 \\
\hline $\begin{array}{l}\text { Urea Formaldehyde } \\
\text { (UF) }\end{array}$ & Formaldehyde & White & 38.3 & 9.8 & 0.226 \\
\hline $\begin{array}{c}\text { Cement coated } \\
\text { urea } \\
\text { ( CCU) }\end{array}$ & Cement & $\begin{array}{l}\text { Dark } \\
\text { Gray }\end{array}$ & 37.2 & 17.4 & 0.468 \\
\hline
\end{tabular}




\section{2-Harvestin Stage Parameters.}

At harvest stage, yield attributes of each plant, seed yield (SY) and straw yield (StY), ton fed $^{-1}$ were recorded from each plot. The yielded seeds were prepared to determine total $N, P$ and $K$ components. Nutrients uptake was determined according to the following formula:

Nutrients uptake (NutU), $\mathbf{~ g ~ f e d ~}^{-1}=$ Nutrient concentration, $\% \times$ grain yield (GY) $\mathrm{kg} \mathrm{fed}^{-1} / 100$

Protein content (\%) of wheat seeds was estimated by multiplying nitrogen percentage by the factor (5.75) according to A.O.A.C. (1990), while, Grain maize oil $\%$ : was extracted by soxhelt apparatus using petroleum ether as a solvent A.O.A.C. (1995).

\section{3-Residues $\mathbf{N}$ in the Soil.}

Surface soil samples $(0-30 \mathrm{~cm})$ from each experimental plot were collected at maximum vegetative growth stage of wheat crop, after harvesting of wheat, before maize sowing and after maize harvesting to determine the available $\mathrm{N}$ in the soil $\left(\mathrm{mg}^{\mathrm{kg}}{ }^{-1}\right)$. Mineral $\mathrm{N}$ was extracted using $2 \mathrm{M}$ potassium chloride and determined according to Kenney and Nelson, (1982) by distillation method.

\section{Economic Evaluation.}

Total cost of cultivation as well as gross income was calculated on the basis of prevailing market for different practices and produces. The total cost of cultivation per feddan was subtracted from the gross income for computing net returns from each treatment (Jadon et al., 2018).

Net return $\left(£\right.$. fed $\left.{ }^{-1}\right)=$ Gross income $(£$. $\left.\mathrm{fed}^{-1}\right)$ - Cost of cultivation $\left(£ . \mathrm{fed}^{-1}\right)$

Benefit cost ratio (BCR) was calculated treatment wise as below.

Benefit Cost Ratio (BCR) = Gross income ICost of cultivation
Statistical Analysis.

All data were subjected to statistical analysis according to Gomez and Gomez, (1984) and the means were compared using least significant difference at $\mathbf{5 \%}$ level were carried out as described by Snedecor and Cochran (1980).

\section{RESULTS AND DISCUSSION}

Collectively, the challenges aim to accelerate the development of innovative fertilizer product technologies and to increase the use of existing enhanced efficiency fertilizers sources (EEFS) like slow release fertilizers (SRF) as example that maintain or increase crop yields and reduce environmental impacts to air, land and water. Cropping Sequences of Wheat and Maize under single fertilization using slow release $\mathbf{N}$ fertilizers (SRNFs) were investigated under alluvial soils conditions located in middle Nile delta.

\section{A- First Growing Season Sequence Wheat Vegetative Growth Parameters and Chlorophyll Content.}

Data tabulated in Table 3 recorded the effect of different nitrogen fertilizer sources and rates on some vegetative growth parameters i.e. shoot height (ShH), cm, shoot fresh weight (ShFW), $\mathrm{g}^{-1}$, shoot dry weight (ShDW), $\mathrm{g}^{-1}$ and chlorophyll content (ChllC), $\mathrm{mg} \mathrm{g}^{-1} \mathrm{FW}$ of wheat plants. A significant increase in all previous parameters by application of all nitrogen fertilizer sources and rates were recorded comparing with control treatment (Conventional urea fertilizer). The results showed positive response to SRNF in the order SCU > UF > CCU respectively under all evaluated rates $(100 \%, 125 \%$ and $150 \%)$ with tremendous increase. It's clear that the ShH, ShFW, ShDW as well as ChllC rising with increasing $\mathbf{N}$ fertilization rate (Table 3 ). The results indicated that application of SRNF (SCU, UF and CCU) comparing with 
Eman H. Abd El-Azeiz, et al.,

urea using $100 \%$ fertilization rate increased ShH by 19.50, 11.24 and $4.46 \%$ respectively. Whereas ShFW and ShDW stimulated with the same types and fertilization rate by $20.77,16.06$ and $4.84 \%$ for ShFW and by $15.70,10.54$ and $6.88 \%$ for ShDW. The same trend of data noticed for ChllC $(a+b)$ by increase 31.23 , 27.61 and $9.78 \%$ respectively. The obtained data appeared the same trend when fertilization rate increased to $\mathbf{1 2 5}$ and $150 \%$ comparing with conventional urea using $100 \%$ fertilization rate wherever the nitrogen nutrient is a responsible nutrient for plant growth and chlorophyll formation (Bojović and Marković, 2009). In addition to the effective role of nitrogen in meristematic activity that increasing cells numbers as well as cell elongation (Zaman et al., 2008).
Slow release nitrogen fertilizers (SRNFs) i.e. SCU, UF and CCU were better than conventional urea (CU) in respect of previous vegetative parameters of wheat. This improving effect of SRNFs may be ascribed for their ability to regulate $N$ releasing according to needs of plant (Haderlein et al., 2011).

On the other hand, the effect of SCU on studied vegetative parameters and chlorophyll content was the best SRNFs. SCU recorded the highest values where it act as a source of both major macronutrients ( $\mathrm{N}$ and $\mathrm{S}$ ) that are needed for plant growth and cell elongation as well as their effective role in chlorophyll synthesis (Mishra et al., 2001 and Ning et al., 2012). This results are in agreement with that obtained by (Shiva et al., 2016 and Hatifield and Parkin (2014).

Table 3. Effect of different sources and rates of SRNFs on some vegetative growth parameters and chlorophyll content $\left(\mathrm{mg} \mathrm{g}^{-1} \mathrm{FW}\right)$ of wheat.

\begin{tabular}{|c|c|c|c|c|c|c|}
\hline \multirow{2}{*}{ Treatments } & \multirow{2}{*}{$\begin{array}{c}\text { Shoot } \\
\text { height } \\
\text { (ShH), cm }\end{array}$} & \multicolumn{2}{|c|}{$\begin{array}{l}\text { Shoot weight (ShW), } \\
\mathrm{g} \mathrm{m}^{-2}\end{array}$} & \multicolumn{3}{|c|}{$\begin{array}{l}\text { Chlorophyll content (ChllC), } \\
\text { mg g-1 } \mathrm{FW}\end{array}$} \\
\hline & & Fresh & Dry & $\mathbf{a}$ & b & $a+b$ \\
\hline CU100\% (control) & 80.89 & 4188.33 & 622.38 & 0.510 & 0.236 & 0.746 \\
\hline SCU100\% & 96.67 & 5058.06 & 720.10 & 0.714 & 0.265 & 0.979 \\
\hline SCU125\% & 97.33 & 5067.00 & 728.12 & 0.717 & 0.269 & 0.986 \\
\hline SCU150\% & 99.83 & 5076.25 & 730.24 & 0.718 & 0.270 & 0.988 \\
\hline UF100\% & 89.98 & 4860.80 & 688.00 & 0.702 & 0.250 & 0.952 \\
\hline UF125\% & 92.97 & 4916.15 & 690.06 & 0.705 & 0.254 & 0.959 \\
\hline UF150\% & 95.17 & 4933.23 & 699.32 & 0.710 & 0.256 & 0.966 \\
\hline CCU100\% & 84.50 & 4391.25 & 652.10 & 0.577 & 0.242 & 0.819 \\
\hline CCU125\% & 86.67 & 4464.30 & 665.20 & 0.645 & 0.244 & 0.889 \\
\hline CCU150\% & 87.01 & 4490.66 & 678.14 & 0.650 & 0.248 & 0.898 \\
\hline F test & *** & *** & *** & *** & $* * *$ & *** \\
\hline LSD at $0.05 \%$ & 1.72 & 8.51 & 8.50 & 0.008 & 0.009 & 0.014 \\
\hline
\end{tabular}


Nutrients Concentration in Wheat Shoot.

Data presented in Table 4 displayed the effect of different nitrogen sources and rates on NPK content of wheat shoot at maximum vegetative growth stage $(75$ days after planting). The results revealed that, increasing nitrogen fertilization rate to 125 and $150 \%$ over the recommended rate caused an increase in NPK content. The results presented that fertilizing using conventional urea with recommended rate $(100 \%)$ gave NPK shoot concentration 2.61, 0.371 and $3.13 \%$ respectively, whereas fertilizing using SRNFs (SCU, UF and CCU) enhanced concentration of the nutrients by $11.11,7.28$ and $3.83 \%$ for $N$ and 15.09 , 6.46 and 1.62 for $P$ and finally increased with $6.37,3.83$ and $1.28 \%$ for $K$. the same trend of data were located when SRNF (SCU, UF and $\mathrm{CCU}$ ) fertilization rate raised up to $150 \%$ from recommended rate. These results are in matching with that recorded by Shiva et al. (2016).

$\mathrm{N}, \mathrm{P}$ and $\mathrm{K}$ nutrients content were
affected significantly by SRNFs
especially SCU, the same result
achieved by Malakouti et al., (2008).
Hassanein et al. (2013) reported that
application of slow release fertilizers
(SRNFs) increased absorption of
phosphorus and potassium wheresulfur
oxidation in soil reducing pH and
increasing availability of nutrients
leading to increase nutrient uptake by
plant.

\section{Wheat Yield and Yield Attribute.}

Data presented in Table 5 indicated that biological yield (BY), (grain (GY) and straw (StY)) and yield attributes i.e. shoot height (ShH), spike length (SpL) and 1000 grain weight (1000 GW) were affected significantly by increasing rates of all $\mathrm{N}$ fertilizer treatments sources (SCU, UF,
$\mathrm{CCU}$ ). The results displayed that there were highly significant differences located due to treatments on ShH, SpL, $1000 \mathrm{GW}, \mathrm{BY}, \mathrm{GY}$ and StY. The results presented that fertilizing using conventional urea with recommended rate $(100 \%)$ gives $\mathrm{ShH}, 98.21 \mathrm{~cm}$; SpL $12.92 \mathrm{~cm}$; 1000GW $50.82 \mathrm{~g}$; BY 8.27 ton fed $^{-1}$; GY 3.47 ton fed $^{-1}$ and StY 4.8 ton fed $^{-1}$. Application of different SRNFs of the first rate enhanced wheat yield and yield attributes by $10.19,7.63,3.89 \%$ for ShH; 15.56, 7.97, 3.87\% for SpL; 12.59, $6.49,1.53 \%$ for $1000 \mathrm{GW}$; $19.95,14.15$, $7.26 \%$ for BY; $37.46,28.24,13.83 \%$ for GY; and $7.29,3.96,2.50 \%$ for StY. The results are in conformity with those of Abdel Nour and Fateh (2011) who indicated a significant increase in yield and yield parameters of wheat plant as nitrogen level was increased up to the recommended rate in two growing seasons, where increasing nitrogen rates caused an increase in number of fertile tillers plant $^{-1}$ which resulted in higher number of spikes $\mathrm{m}^{-2}$, and this may be due to the effective role of nitrogen in building up new tissues leading to increasing grain and straw yield (Hamd Alla et al., 2015). These results are also in matching with that recorded by Abd ElRazek and El-Sheshtawy (2013).

SRNFs recorded a significant values in all studied parameters comparing with conventional urea (CU), the highest values of $1000 \mathrm{GW}$ and yield were indicated by (SCU) followed by (UF), then (CCU) and lately (CU). These results may be due to the regulation of nutrient release which makes nutrient more efficiency for plant than conventional urea as well as reducing $\mathbf{N}$ losses by leaching and providing roots by $a$ constant supply of required nutrient (Trenkel, 2010). 
Eman H. Abd El-Azeiz, et al.,

Table 4. Effect of different sources and rates of SRNFs on nutrients concentration (\%) of wheat shoot at maximum vegetative growth stage.

\begin{tabular}{|c|c|c|c|}
\hline \multirow{2}{*}{ Treatments } & \multicolumn{3}{|c|}{ Nutrients concentration (\%) } \\
\cline { 2 - 4 } & $\mathrm{N}$ & $\mathrm{P}$ & $\mathrm{K}$ \\
\hline CU100\%(control) & 2.61 & 0.371 & 3.13 \\
\hline SCU100\% & 2.90 & 0.427 & 3.33 \\
\hline SCU125\% & 2.92 & 0.434 & 3.35 \\
\hline SCU150\% & 2.95 & 0.440 & 3.38 \\
\hline UF100\% & 2.80 & 0.395 & 3.25 \\
\hline UF125\% & 2.84 & 0.410 & 3.29 \\
\hline UF150\% & 2.87 & 0.416 & 3.31 \\
\hline CCU100\% & 2.71 & 0.377 & 3.17 \\
\hline CCU125\% & 2.75 & 0.382 & 3.20 \\
\hline CCU150\% & 2.77 & 0.391 & 3.22 \\
\hline F test & $* * *$ & $* * *$ & $* * *$ \\
\hline LSD at $0.05 \%$ & 0.085 & 0.008 & 0.085 \\
\hline
\end{tabular}

Table 5. Effect of different sources and rates of SRNFs on yield and yield attributes of wheat plant.

\begin{tabular}{|c|c|c|c|c|c|c|}
\hline Treatments & $\begin{array}{l}\text { Shoot } \\
\text { height }\end{array}$ & $\begin{array}{l}\text { Spike } \\
\text { length }\end{array}$ & $1000 \mathrm{GW}, \mathrm{g}$ & $\begin{array}{c}\text { Bio } \\
\text { Yield } \\
\text { (BY) }\end{array}$ & $\begin{array}{l}\text { Grain } \\
\text { Yield } \\
\text { (GY) }\end{array}$ & $\begin{array}{l}\text { Straw } \\
\text { Yield } \\
\text { (StY) }\end{array}$ \\
\hline & ( & (GLL), & & \multicolumn{3}{|c|}{ ton fed ${ }^{-1}$} \\
\hline CU100\% (control) & 98.21 & 12.92 & 50.82 & 8.27 & 3.47 & 4.80 \\
\hline SCU100\% & 108.22 & 14.93 & 57.22 & 9.92 & 4.77 & 5.15 \\
\hline SCU125\% & 108.88 & 15.25 & 57.64 & 9.98 & 4.80 & 5.18 \\
\hline SCU150\% & 109.71 & 15.90 & 58.30 & 10.1 & 4.88 & 5.22 \\
\hline UF100\% & 105.71 & 13.95 & 54.12 & 9.44 & 4.45 & 4.99 \\
\hline UF125\% & 106.54 & 14.15 & 54.63 & 9.56 & 4.54 & 5.02 \\
\hline UF150\% & 107.88 & 14.40 & 55.00 & 9.69 & 4.64 & 5.05 \\
\hline CCU100\% & 102.04 & 13.42 & 51.60 & 8.87 & 3.95 & 4.92 \\
\hline CCU125\% & 102.21 & 13.66 & 52.91 & 8.93 & 3.99 & 4.94 \\
\hline CCU150\% & 103.71 & 13.78 & 53.33 & 9.25 & 4.29 & 4.96 \\
\hline F test & $* \star *$ & $\star \star * *$ & $* * *$ & $* * *$ & $\star \star *$ & $* \star *$ \\
\hline LSD at $0.05 \%$ & 0.170 & 0.85 & 0.08 & 0.085 & 0.16 & 0.08 \\
\hline
\end{tabular}


In addition to sulfur coated urea (SCU) act as a source of $S$ which a responsible macronutrient for plant growth and yield production as well as an enhanced efficiency of nitrogen fertilizer (Shiva et al., 2016).

NPK and Protein Content and Nutrients Uptake in Grains.

Application of $\mathbf{N}$ tested fertilizers were significantly increased NPK concentration and uptake in wheat grains as well as grain content of protein as shown in Table 6 and Figs. 1 (a, b and c). Fertilizing with $\mathrm{N}$ recommended rate (100\%) using SRNFs especially SCU induced higher NPK and protein content in grain $(2.35,0.289,1.38$ and $13.51 \%$ respectively) than conventional urea $(2.08, \quad 0.265, \quad 1.19$ and $11.96 \%$ respectively) with slight response to the other two SRNFs (UF and CCU). The recorded data denoted that raising $\mathrm{N}$ fertilizer up to 125 and $150 \%$ over the recommended rate had a positive significant effect on $\mathrm{N}$ concentration and uptake. The highest values were recorded with $150 \%$ fertilization rate using SCU fertilizer $(2.39,0.293,1.43$ and $13.74 \%$ for NPK and protein content). Shiva et al. (2016) found that more nitrogen applied produces a linear increase in nitrogen uptake. The poor $\mathrm{N}$ uptake associated with conventional urea treatment in alkaline soil may be due to the loss of nutrient through large volatilization and leaching (Shavive and Mikkelsen, 1993 and Nasima et al., 2010).

SRNFs also enhanced $P$ and $K$ uptake as well as $N$ as a result of the natural of coated material which helps in obtaining nutrients, and thus increase yield production and nutrients content (Trenkel, 2010).

SRNFs achieved higher protein concentration than conventional urea and this result may be due to supply of sufficient $\mathrm{N}$ that led to increase protein concentration (Shiva et al., 2016).

Table 6. Effect of different sources and rates of SRNFs on protein and nutrient concentration (\%) in grains of wheat plant.

\begin{tabular}{|c|c|c|c|c|}
\hline \multirow{2}{*}{ Treatments } & \multicolumn{4}{|c|}{ Nutrients and protein concentration (\%) } \\
\cline { 2 - 5 } & $\mathrm{N}$ & $\mathrm{P}$ & $\mathrm{K}$ & Protein \\
\hline CU100\%(control) & 2.08 & 0.265 & 1.19 & 11.96 \\
\hline SCU100\% & 2.35 & 0.289 & 1.38 & 13.51 \\
\hline SCU125\% & 2.37 & 0.291 & 1.40 & 13.63 \\
\hline SCU150\% & 2.39 & 0.293 & 1.43 & 13.74 \\
\hline UF100\% & 2.27 & 0.280 & 1.30 & 13.05 \\
\hline UF125\% & 2.29 & 0.285 & 1.33 & 13.17 \\
\hline UF150\% & 2.33 & 0.287 & 1.35 & 13.40 \\
\hline CCU100\% & 2.18 & 0.269 & 1.22 & 12.54 \\
\hline CCU125\% & 2.21 & 0.273 & 1.24 & 12.71 \\
\hline CCU150\% & 2.23 & 0.277 & 1.27 & 12.82 \\
\hline F test & $* * *$ & $* * *$ & $* * *$ & $*$ *** \\
\hline LSD at $0.05 \%$ & 0.085 & 0.009 & 0.086 & 0.048 \\
\hline
\end{tabular}


Eman H. Abd El-Azeiz, et al.,

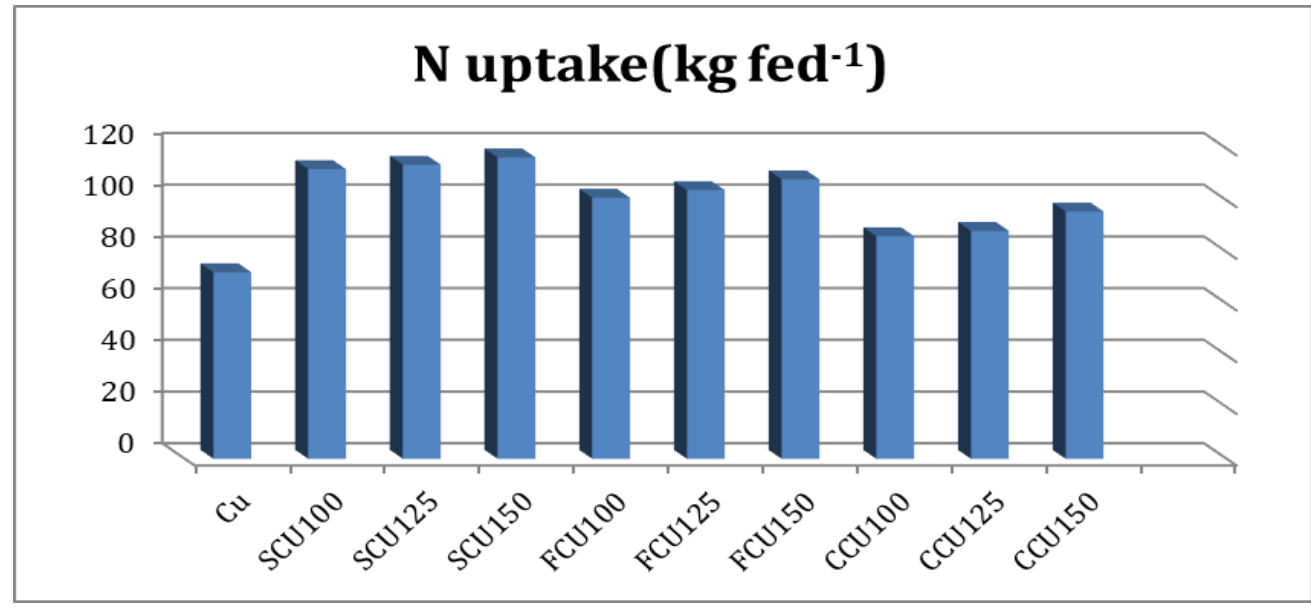

Fig (1a): Effect of different sources and rates of SRNFs on $\mathrm{N}$ uptake $\left(\mathrm{kg} \mathrm{fed}^{-1}\right)$ in grains of wheat plant.

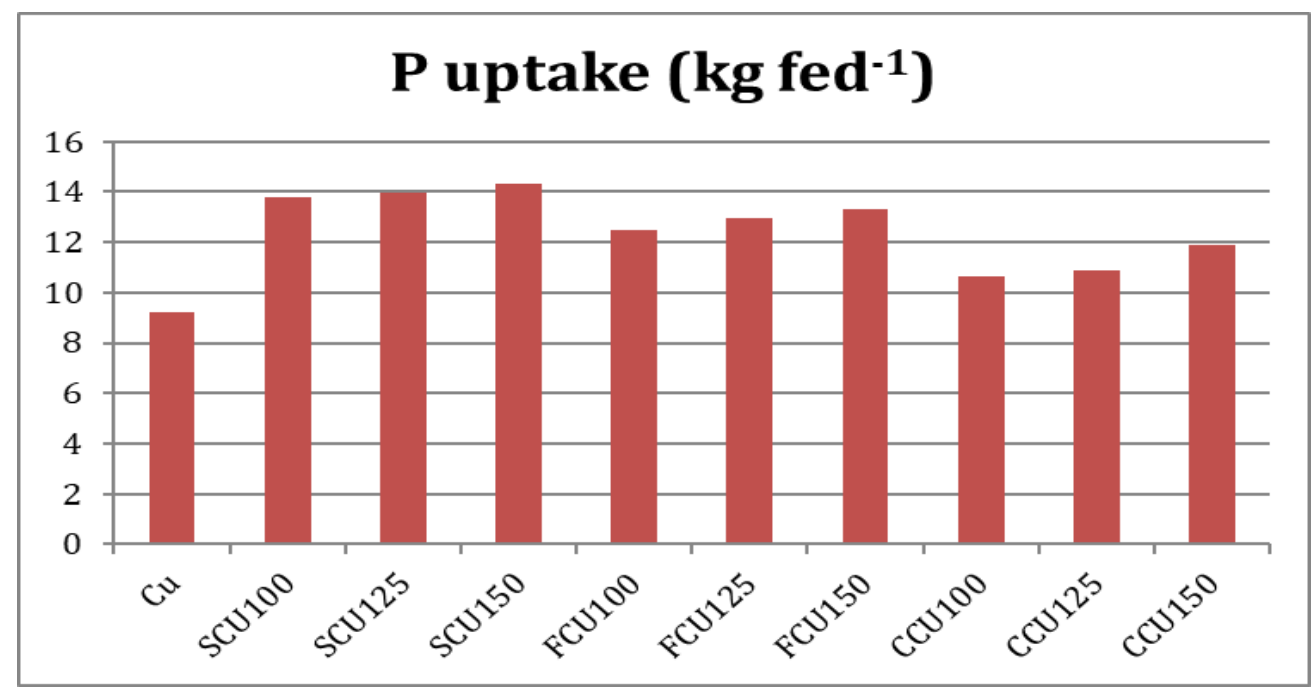

Fig (1b): Effect of different sources and rates of SRNFs on P uptake $\left(\mathrm{kg} \mathrm{fed}^{-1}\right)$ in grains of wheat plant.

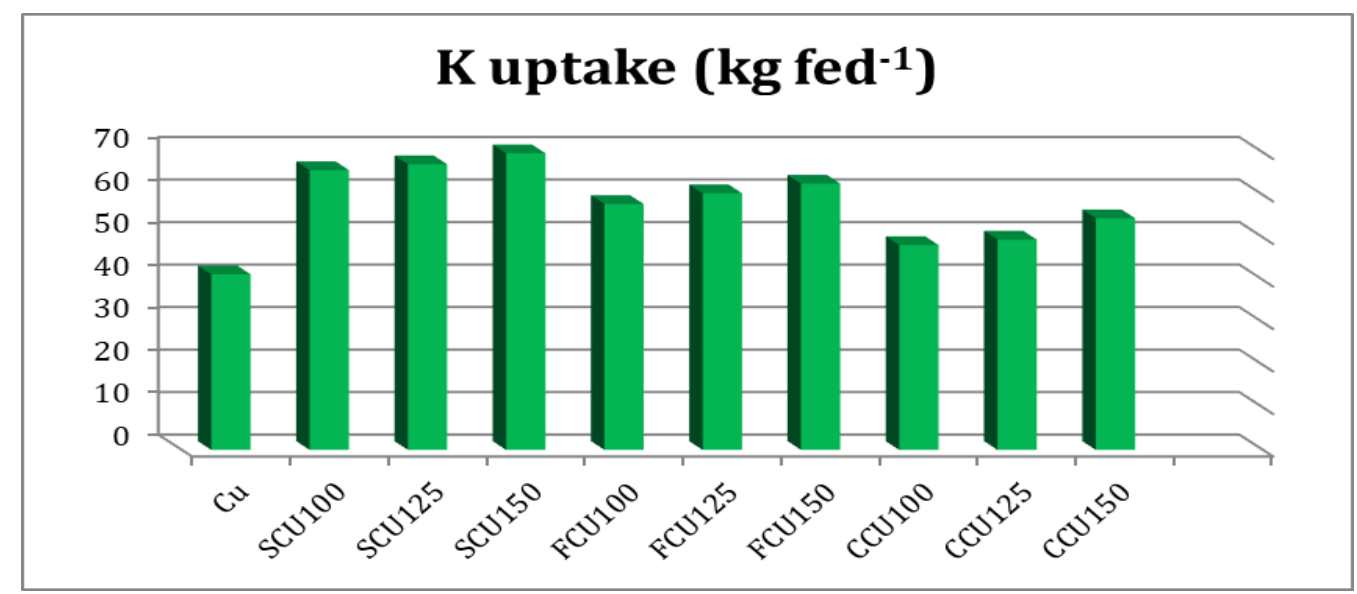

Fig (1c): Effect of different sources and rates of SRNFs on K uptake $\left(\mathrm{kg} \mathrm{fed}^{-1}\right)$ in grains of wheat plant. 


\section{B-Second Growing Season Sequence:}

Maize Vegetative Growth Parameters and Chlorophyll Content

Data recorded in Table 7 elucidated a significant effect of all tested treatments on studied vegetative growth parameters such as shoot height $(\mathrm{ShH}), \mathrm{cm}$, shoot fresh weight (ShFW), $\mathrm{g}^{-1}$, shoot dry weight (ShDW), $\mathrm{g}^{-1}$ and leaf area (LA) $\mathrm{cm}^{-2}$ as well as chlorophyll content (ChIlC), $\mathrm{mg}$ $\mathrm{g}^{-1} \mathrm{FW}$ of maize plant. On the other hand, there were a significant differences between the different residual SRNFs were observed. Similar results were reported by Jadon et al. (2018). The results showed a positive response to different residual SRNFs in the order CCU > SCU >UF respectively under all evaluated rates $(100 \%, 125 \%$ and $150 \%)$ over CU. This result may be due to their ability to regulate $\mathrm{N}$ releasing according to needs of plant (Mikkelsen et al., 1994).

The results exhibited that the residual of SRNFs (CCU, SCU and UF) achieved the highest values of ShH (305.0, 285.5 and 267.84) respectively. Whereas ShFW, ShDW and LA respond to the same type and fertilization rate with values 378.30 , 344.66 and 297.80 for ShFW, 46.38, 42.25 and 36.51 for ShDW and 562.51, 532.55 and 491.50 for LA. The same trend of data noticed by ChIIC $(a+b)$ where the values were $0.311,0,290$ and 0.246 respectively comparing with urea using $100 \%$ fertilization rate.

It's clear that ShH, ShFW, ShDW, LA and ChllC raising with residual effect of SRNFs at rates over the recommended rate i.e. 125 and $150 \%$. This result is in harmony with that recorded by Shehzad et al., (2012) who found that by increasing nitrogen levels, fresh weight per plant, dry weight per plant and chlorophyll content of maize were increased. As well as there was a close link between nitrogen plant growth and chlorophyll formation (Bojović and Marković, 2009). These results are in matching with that recorded by Hassan et al., (2010).

Table 7. Effect of different sources and rates of residual SRNFs and additional CU on some vegetative growth parameters and chlorophyll content ( $\left.\mathrm{mg} \mathrm{g} \mathrm{FW}^{-1}\right)$ of Maize.

\begin{tabular}{|c|c|c|c|c|c|c|c|}
\hline \multirow[t]{2}{*}{ Treatments } & \multirow{2}{*}{$\begin{array}{c}\text { Shoot } \\
\text { height } \\
\text { (ShH), cm }\end{array}$} & \multicolumn{2}{|c|}{$\begin{array}{c}\text { Shoot weight } \\
\left(\text { ShW), } \mathbf{g}^{-1}\right.\end{array}$} & \multirow{2}{*}{$\begin{array}{l}\text { Leaf area } \\
\text { (LA), } \mathbf{c m}^{2}\end{array}$} & \multicolumn{3}{|c|}{$\begin{array}{c}\text { Chlorophyll content } \\
\text { (ChllC), } \\
\text { mg .g FW-1 }^{-1}\end{array}$} \\
\hline & & Fresh & Dry & & $\mathbf{a}$ & b & $a+b$ \\
\hline CU100\%(control) & 253.65 & 276.32 & 33.87 & 475.81 & 0.172 & 0.056 & 0.228 \\
\hline SCU100+50\%CU & 285.50 & 344.66 & 42.25 & 532.55 & 0.220 & 0.070 & 0.290 \\
\hline SCU125+50\%CU & 290.66 & 356.32 & 43.68 & 548.27 & 0.226 & 0.073 & 0.299 \\
\hline SCU150 +50\%CU & 300.80 & 366.50 & 44.93 & 553.26 & 0.230 & 0.076 & 0.306 \\
\hline UF100+50\%CU & 267.84 & 297.80 & 36.51 & 491.50 & 0.186 & 0.060 & 0.246 \\
\hline UF125+50\%CU & 275.12 & 316.05 & 38.74 & 508.12 & 0.192 & 0.064 & 0.256 \\
\hline UF150+50\%CU & 281.32 & 332.12 & 40.71 & 525.92 & 0.205 & 0.066 & 0.271 \\
\hline CCU100+50\%CU & 305.00 & 378.30 & 46.38 & 562.51 & 0.236 & 0.075 & 0.311 \\
\hline CCU125+50\%CU & 315.60 & 386.15 & 47.34 & 575.55 & 0.242 & 0.078 & 0.320 \\
\hline CCU150+50\%CU & 321.32 & 392.62 & 48.13 & 583.38 & 0.248 & 0.082 & 0.330 \\
\hline F test & $* * *$ & *** & *** & *** & $* * \star$ & $\star \star \star *$ & *** \\
\hline LSD 5\% & 1.62 & 8.51 & 0.080 & 3.42 & 0.0085 & 0.002 & 0.004 \\
\hline
\end{tabular}


Eman H. Abd El-Azeiz, et al.,

Nutrients Concentration in Maize Shoot.

Data presented in Table 8 showed the effect of residual different SRNFs on NPK concentration in maize shoot plant at maximum vegetative stage growth. The results showed that, the residual of SRNFs recorded the highest effect in NPK content in maize shoot. The superior treatments were all $\mathrm{CCU}$ applications followed by SCU treatments, where residual of CCU, SCU and UF using at $100 \%$ fertilization rate enhanced NPK shoot concentration by $16.54,12.23$ and $3.23 \%$ for $N$; $31.61,16.77$ and $3.87 \%$ for $P$ and $18.11,10.24$ and $1.97 \%$ for K. Abou Zied et al., (2014) revealed that different SRNFs affected significantly NPK content of maize comparing with conventional urea (CU). Similar results were recorded by Signor and Barbiani (2013) and ElGhamry et al., (2016). The same trend of data was observed by residual of SRNFs using 125 and $150 \%$ fertilization rate. These results are in harmony with
Almodares et al., (2009); Mello et al., (2017) and EL-Metwally et al., (2019).

\section{Maize Yield and Yield Attributes.}

Data presented in Table 9 indicated that a significant increases in yield and yield attributes i.e., shoot height (ShH), ear length (EL), ear diameter (ED), 100grain weight (100 GW), biological (BY), grain (GY) and straw yield (StY) by residual of all SRNFs.

Tabulated data indicated that conventional urea (CU) treatment application at recommended rate $(100 \%)$ recorded ShH, $278.40 \mathrm{~cm}$; EL, $16.55 \mathrm{~cm}$; $E D, 3.80 \mathrm{~cm} ; 100 \mathrm{GW}, 31.30 \mathrm{~g}$; BY, 8.53 ton fed $^{-1}$; GY,3.20 ton fed ${ }^{-1}$ and StY 5.33 ton fed $^{-1}$. Residual of CCU, SCU and UF using at $100 \%$ fertilization rate increased maize yield and yield attributes by 19.32 , 12.18 and $4.45 \%$ for $\mathrm{ShH} ; 36.25,24.60$ and $14.80 \%$ for EL; $13.68,7.89$ and $3.94 \%$ for ED; $16.96,11.15$ and $0.575 \%$ for $100 \mathrm{GW}$; 7.26, 4.45 and $0.47 \%$ for BY; $9.38,3.75$ and $0 \%$ for GY; and $6.00,4.88$ and $0.75 \%$ for StY.

Table 8. Effect of different sources and rates of residual SRNFs and additional CU on nutrient concentration at maximum vegetative growth stage of maize shoot.

\begin{tabular}{|c|c|c|c|}
\hline \multirow[t]{2}{*}{ Treatments } & \multicolumn{3}{|c|}{$\begin{array}{c}\text { Nutrients concentration } \\
\text { (\%) }\end{array}$} \\
\hline & $N$ & $\mathbf{P}$ & $K$ \\
\hline CU100\% (control) & 2.78 & 0.155 & 2.54 \\
\hline SCU100+50\%CU & 3.12 & 0.181 & 2.80 \\
\hline SCU125+50\%CU & 3.16 & 0.187 & 2.85 \\
\hline SCU150 +50\%CU & 3.19 & 0.195 & 2.90 \\
\hline UF100+50\%CU & 2.87 & 0.161 & 2.59 \\
\hline UF125+50\%CU & 2.99 & 0.167 & 2.66 \\
\hline UF150+50\%CU & 3.04 & 0.175 & 2.74 \\
\hline CCU100+50\%CU & 3.24 & 0.204 & 3.00 \\
\hline CCU125+50\%CU & 3.31 & 0.213 & 3.02 \\
\hline CCU150+50\%CU & 3.36 & 0.207 & 3.10 \\
\hline F test1 & $* * *$ & $* \star *$ & $* * *$ \\
\hline LSD5\% & 0.038 & 0.006 & 0.065 \\
\hline
\end{tabular}


Table 9. Effect of different sources and rates of residual SRNFs and additional CU on yield and yield attributes of maize.

\begin{tabular}{|c|c|c|c|c|c|c|c|}
\hline \multirow{3}{*}{ Treatments } & \multicolumn{3}{|c|}{ (cm) } & \multirow{3}{*}{$\begin{array}{c}100 \\
\text { Grain } \\
\text { weight } \\
(100 \mathrm{GW}), \\
\mathrm{g}\end{array}$} & \multirow{2}{*}{$\begin{array}{l}\text { Bio. } \\
\text { yield } \\
\text { (BY) }\end{array}$} & \multirow{2}{*}{$\begin{array}{l}\text { Grain } \\
\text { yield } \\
\text { (GY) }\end{array}$} & \multirow{2}{*}{$\begin{array}{l}\text { Straw } \\
\text { yield } \\
\text { (StY) }\end{array}$} \\
\hline & \multirow{2}{*}{$\begin{array}{l}\text { Shoot } \\
\text { Height } \\
\text { (ShH) }\end{array}$} & \multirow{2}{*}{$\begin{array}{l}\text { Ear } \\
\text { length } \\
\text { (EL) }\end{array}$} & \multirow{2}{*}{$\begin{array}{c}\text { Ear } \\
\text { diameter } \\
\text { (ED) }\end{array}$} & & & & \\
\hline & & & & & \multicolumn{3}{|c|}{ Ton fed $^{-1}$} \\
\hline CU100\%(control) & 278.40 & 16.55 & 3.80 & 31.30 & 8.53 & 3.20 & 5.33 \\
\hline SCU100+50\%CU & 312.30 & 20.62 & 4.10 & 34.79 & 8.91 & 3.32 & 5.59 \\
\hline SCU125+50\%CU & 321.26 & 20.75 & 4.12 & 35.34 & 8.99 & 3.37 & 5.62 \\
\hline SCU150 +50\%CU & 325.55 & 21.25 & 4.32 & 35.20 & 9.08 & 3.43 & 5.65 \\
\hline UF100+50\%CU & 290.80 & 19.0 & 3.95 & 31.48 & 8.57 & 3.20 & 5.37 \\
\hline UF125+50\%CU & 298.22 & 19.66 & 3.99 & 32.57 & 8.69 & 3.26 & 5.43 \\
\hline UF150+50\%CU & 303.59 & 20.25 & 4.05 & 33.74 & 8.82 & 3.29 & 5.53 \\
\hline CCU100+50\%CU & 332.22 & 22.55 & 4.32 & 36.61 & 9.15 & 3.50 & 5.65 \\
\hline CCU125+50\%CU & 343.33 & 23.75 & 4.50 & 37.43 & 9.22 & 3.53 & 5.69 \\
\hline CCU150+50\%CU & 355.10 & 24.0 & 4.62 & 38.84 & 9.29 & 3.57 & 5.72 \\
\hline$F$ test & $* \star *$ & $* * *$ & $* * *$ & $* * *$ & $* \star \star *$ & $* \star *$ & $* * *$ \\
\hline LSD5\% & 1.62 & 0.740 & 0.032 & 0.080 & 0.085 & 0.085 & 0.085 \\
\hline
\end{tabular}

It's clear that residual of SRNFs treatments application causes a gradual increase in most studied parameters as a result of availability of needed $\mathrm{N}$ for a long time as plant need (Gagnon et al., 2012); the superior effect of treatments were obtained with residual of CCU. Jadon et al., (2018) recorded that SRNFs increasing yield and yield attributes of maize comparing with conventional urea. It could be explained by the low solubility of CCU than other SRNFs, controlling of nutrient release and providing more efficient nutrients to the roots.

Application of $\mathrm{CU}$ using additional $50 \%$ fertilization rate with residual of $\mathrm{CCU}$ $(150 \%)$ achieved highest values of all yield parameters. These results may be due to the effective role of nitrogen on the meristmatic activity of plant tissues, as well as its role in proteins, nucleic acid and many other important substances of plant cell formation that lead to the highest yield producing. These results are in matching with that reported by Mukhtar et al. (2011).
NPK, Oil Content and Nutrients Uptake in Grains.

Results in Table 10 and Figs 2 (a, b and c) revealed that all applied treatments had a positive effects on grains NPK and oil content of maize.

The residual amounts from SRNFs application caused a significant increase in NPK content in maize grains. Residual effect of CCU using $100 \%$ fertilization rate recorded the highest NPK and oil content in grains $(2.09,0.134,1.46$ and $5.20 \%$ respectively) than that of CU $(1.74,0.101$, 1.11 and $4.57 \%$ respectively). Tabulated data recorded that residual influence of SRNFs at fertilization rate 125 and $\mathbf{1 5 0} \%$ over recommended fertilization rates significantly increased NPK and oil content of maize grains comparing with CU using fertilization rate at $100 \%$ recommended dose (control). Abou-Zied et al., (2014) concluded that increasing rate of nitrogen increasing content of NPK. On the other hand residual effect of SRNFs increased oil content in maize grains, this result is in matching with that obtained by Signor and Barbiani (2013). 
Eman H. Abd El-Azeiz, et al.,

Table 10. Effect of different sources and rates of residual SRNFs and additional CU on oil and nutrient concentration (\%) in maize grains.

\begin{tabular}{|c|c|c|c|c|}
\hline \multirow{2}{*}{ Treatments } & \multicolumn{4}{|c|}{ Nutrients and oil concentration } \\
& \multicolumn{4}{|c|}{ (\%) } \\
\cline { 2 - 5 } & $\mathrm{N}$ & $\mathrm{P}$ & $\mathrm{K}$ & Oil \\
\hline CU100\% (control) & 1.74 & 0.101 & 1.11 & 4.57 \\
\hline SCU100+50\%CU & 1.92 & 0.121 & 1.29 & 4.90 \\
\hline SCU125+50\%CU & 2.01 & 0.126 & 1.35 & 4.85 \\
\hline SCU150+50\%CU & 2.04 & 0.125 & 1.40 & 4.78 \\
\hline UF100+50\%CU & 1.79 & 0.106 & 1.16 & 4.73 \\
\hline UF125+50\%CU & 1.83 & 0.111 & 1.20 & 4.67 \\
\hline UF150+50\%CU & 1.88 & 0.116 & 1.23 & 4.60 \\
\hline CCU100+50\%CU & 2.09 & 0.134 & 1.46 & 5.20 \\
\hline CCU125+50\%CU & 2.13 & 0.138 & 1.49 & 5.17 \\
\hline CCU150+50\%CU & 2.17 & 0.141 & 1.54 & 5.08 \\
\hline F test & $\star \star *$ & $\star \star *$ & $\star \star *$ & $\star \star$ \\
\hline LSD5\% & 0.076 & 0.002 & 0.038 & 0.045 \\
\hline
\end{tabular}

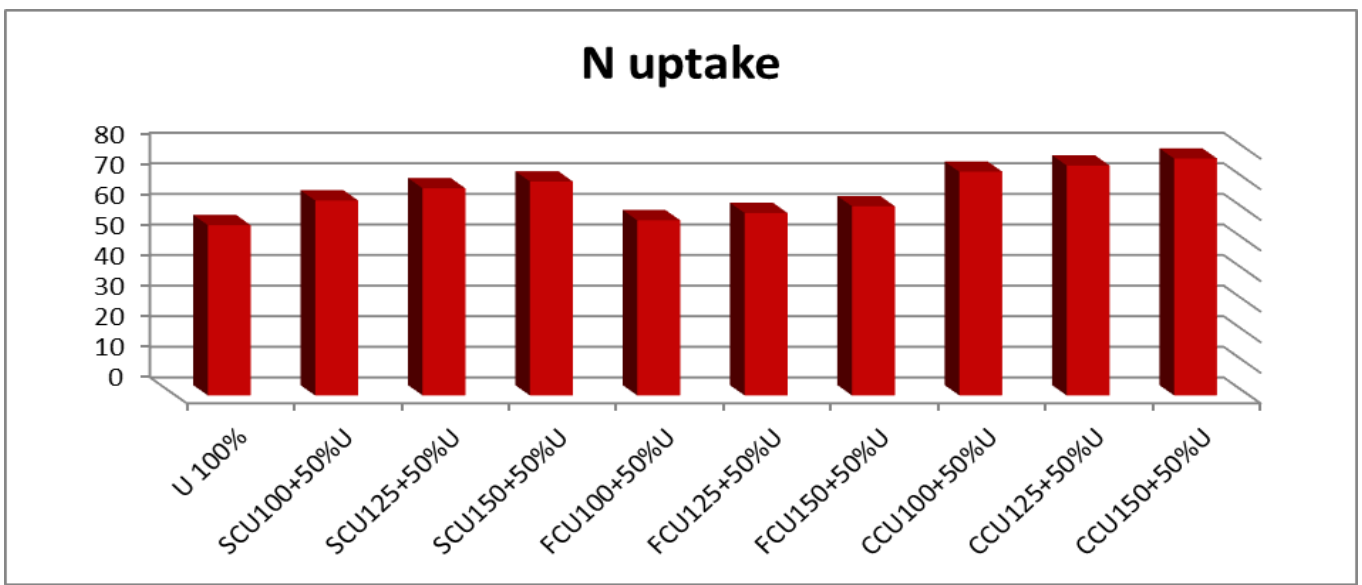

Fig. (2a): Residual effect of SRNFs and additional CU on $\mathrm{N}$ uptake $\left(\mathrm{Kg} \mathrm{fed}^{-1}\right)$ of maize grains.

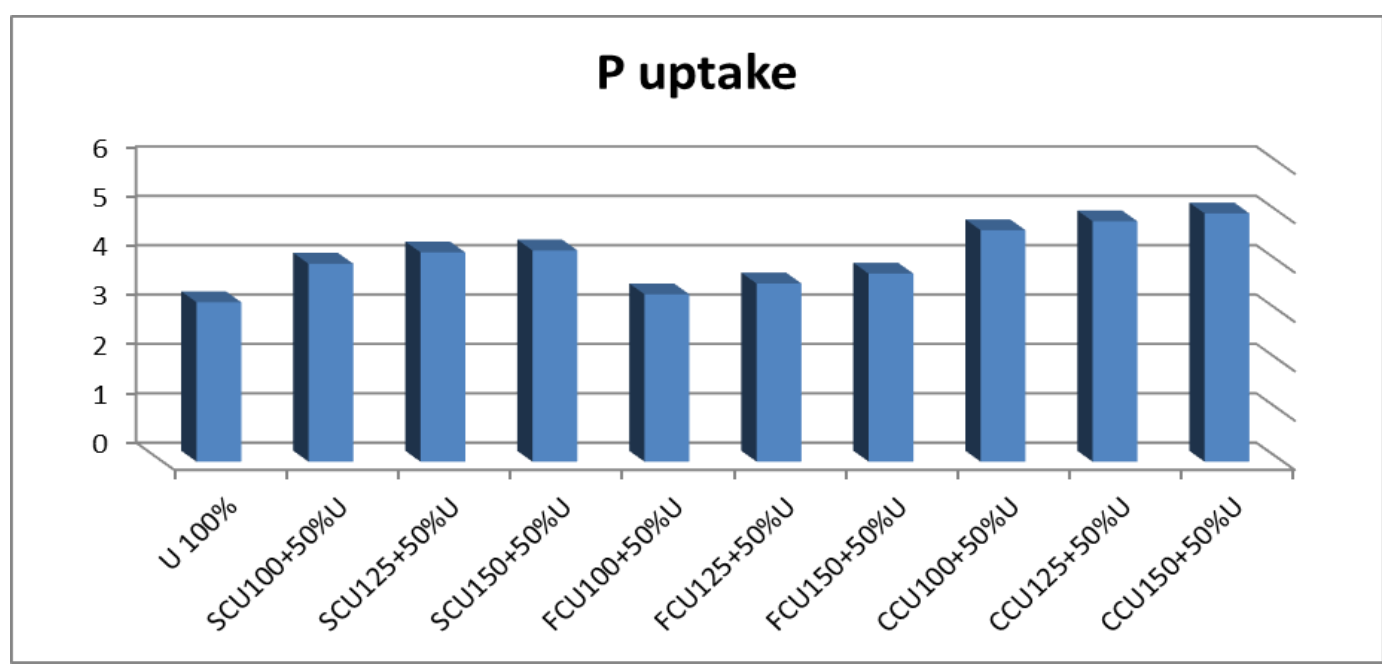

Fig. (2b): Residual effect of SRNFs and additional CU on P uptake $\left(\mathrm{Kg} \mathrm{fed}^{-1}\right)$ of maize grains. 


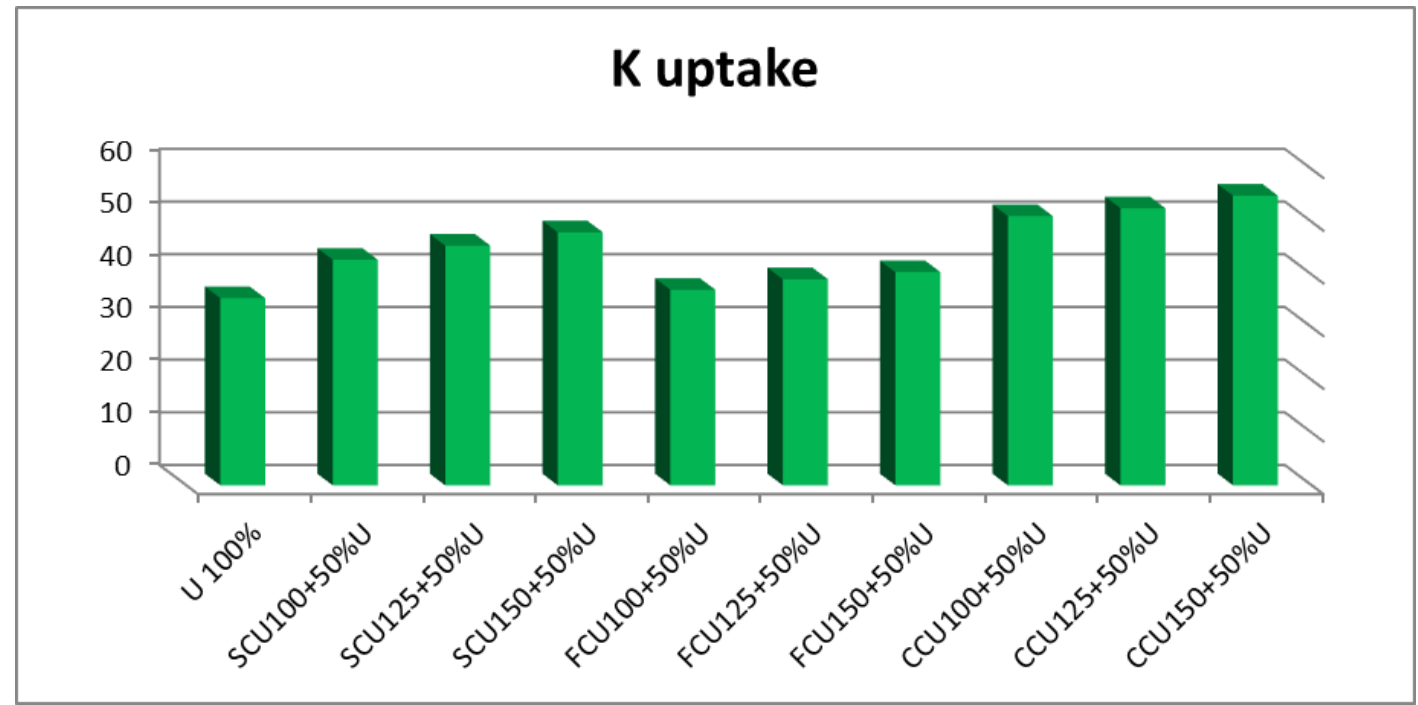

Fig. (2c): Residual effect of SRNFs and additional CU on $\mathrm{K}$ uptake $\left(\mathrm{Kg} \mathrm{fed}^{-1}\right)$ of maize grains.

\section{Residual N in Soil.}

Soil samples were collected during the two successive growing seasons of wheat and maize (winter and summer growing seasons) to monitors available soil $\mathbf{N}$ content. Data tabulated in Table 11 showed the available soil nitrogen content in the soil surface layer $(0-30 \mathrm{~cm})$ during maximum vegetative growth stage (75 days after planting) of wheat, after wheat harvesting, before maize sowing and finally after maize harvesting. From tabulated data it's clear that all treatments positively affected the availability of nitrogen content in the soil during all studied periods comparing with conventional urea (CU).

Firstly, during maximum wheat vegetative growth (75 days after planting) available nitrogen increased gradually, due to release of the SRNFs which recorded the highest values of available soil $\mathbf{N}$ comparing with conventional urea (CU) under $100 \%$ fertilization rate where UF, SCU and CCU induced 101.35, 98.85 and $90.65 \mathrm{mg} \mathrm{kg}^{-1}$ respectively. After harvesting we noticed that the highest values of available soil $\mathbf{N}$ was recorded by CCU $\left(87.55 \mathrm{mg} \mathrm{Kg}^{-1}\right)$ followed by SCU (86.85 $\left.\mathrm{mg} \mathrm{Kg}^{-1}\right)$, UF (85.35 $\mathrm{mg} \mathrm{Kg}^{-1}$ ) and lately $\mathrm{CU}\left(80.55 \mathrm{mg} \mathrm{Kg}^{-1}\right)$ using $100 \%$ fertilization rate. The same trend was occurred before maize sowing with decrease in $\mathrm{N}$ content due to voltalization.

Secondly, after maize harvesting results of $\mathrm{N}$ concentration elucidated that the highest individual effect of SRNFs residual values recorded in case of $\mathrm{CCU}$ fertilizer, where $\mathrm{CCU}$ using at $100 \%$ fertilization rate recorded $80.20 \mathrm{mg} \mathrm{Kg}^{-1}$ while SCU and UF using at the same fertilization rate showed $\mathbf{6 9 . 6 5}$ and $\mathbf{5 7 . 5 0}$ $\mathrm{mg} \mathrm{Kg}^{-1}$ respectively, and the lowest available soil $\mathrm{N}\left(65.35 \mathrm{mg} \mathrm{Kg}^{-1}\right)$ achieved by $\mathrm{CU}$. These results may be due to the low solubility of coating layer for CCU comparing with the other three urea types. Mello et al. (2017) indicated that losses of nitrogen through voltalization reduced by approximately $50 \%$ in case of coated urea application.

When applied conventional urea (CU) to the soil, urea hydrolyzed through a series of biological, chemical and physical reactions urease enzyme to $\mathrm{NH}^{4+}$ which oxidized to $\mathrm{NO}_{3}{ }^{-}$that loss by leached or denitrified (EI-Ghamery et al., 2016).

Ladha et al., (2005) and Galloway et al., (2004) indicated that crops used 
Eman H. Abd El-Azeiz, et al.,

approximately $30-50 \%$ from the applied $\mathrm{N}$ and this may be due to losses of $\mathrm{N}$ through leaching, volatilization, nitrification, denitrification and decomposition. On the other hand, the least remaining amount from $\mathrm{N}$ fertilizer after crop recovery and losses still in soil causing residual $\mathrm{N}$ effect and are available for subsequent crops (Krupnik et al., 2004).

In a wheat/maize cropping sequence experiment the residual $\mathrm{N}$ recovery of applied fertilizer to wheat was $5-10 \%$ in the later maize crop and $1.7-3.5 \%$ in the subsequent wheat crop and this recovery act as a source of $\mathrm{N}$ in cropping sequence (Jia et al., 2011).

Releasing nutrients from slow release fertilizers ranging between (3-12 months) where it depends on different factors i.e.: coating solubility, rate of hydrolysis, moisture, temperature of the soil, coating thickness, micro cracks number in coating surface and granule size of fertilizer (Pereira, 2009).
SRNFs can be classified according to solubility into different types; in this research SCU and CCU are examples of fertilizers in which the release is controlled by some physical, chemical and microbial processes (Trenkel, 2010).

While, UF is example of fertilizers that has a low solubility with organic-N compounds that decomposed biologically or chemically and it's widely used in warmer climates where it be more effective at higher temperatures (Wilson et al., 2009).

\section{Economic Analysis:}

Gross income is an indicator to the benefit that farmers can obtain. While, net return determines farmers' actual income. On the other hand, benefit cost ratio (BCR) is the overall relationship between the relative costs and benefits. Economically if a BCR greater than 1.0, the project is expected to deliver a positive net present value to a firm and its investors (Jadon et al., 2018).

Table 11. Effect of different SRNFs on available $\mathrm{N}$ content in soil $\left(\mathrm{mg} \mathrm{kg}^{-1}\right)$ at different stages during wheat-maize cropping sequence system.

\begin{tabular}{|c|c|c|c|c|}
\hline \multirow{2}{*}{ Treatments } & \multicolumn{4}{|c|}{ Available N in soil $\left(\mathrm{mg} \mathrm{kg}^{-1}\right)$} \\
\cline { 2 - 5 } & $\begin{array}{r}\text { At vegetative } \\
\text { stage of wheat }\end{array}$ & $\begin{array}{r}\text { After wheat } \\
\text { harvesting }\end{array}$ & $\begin{array}{c}\text { Before maiz } \\
\text { sowing }\end{array}$ & $\begin{array}{c}\text { After maize harvestin } \\
+50 \% \text { CU }\end{array}$ \\
\hline CU & 89.55 & 80.55 & 54.25 & 65.35 \\
\hline SCU100\% & 98.85 & 86.85 & 68.95 & 69.65 \\
\hline SCU125\% & 99.50 & 88.95 & 70.65 & 73.40 \\
\hline SCU150\% & 100.88 & 90.65 & 72.06 & 77.65 \\
\hline UF100\% & 101.35 & 85.35 & 67.60 & 57.50 \\
\hline UF125\% & 102.65 & 88.55 & 69.40 & 62.45 \\
\hline UF150\% & 106.20 & 89.45 & 70.75 & 65.92 \\
\hline CCU100\% & 90.65 & 87.55 & 74.55 & 80.20 \\
\hline CCU125\% & 96.95 & 89.75 & 76.45 & 84.00 \\
\hline CCU150\% & 99.65 & 91.55 & 79.05 & 85.88 \\
\hline F test & $* * *$ & $* * *$ & $* * *$ & $* * *$ \\
\hline LSD at $0.05 \%$ & 0.085 & 0.084 & 0.085 & 0.085 \\
\hline
\end{tabular}


Data tabulated in Table 12 declared that there was a differences in gross income, net return and benefit cost ratio between all treatments in wheat and maize crops, respectively. The highest cost of cultivation in wheat crop recorded by SRNFs comparing with conventional urea (CU). CCU using at $\mathbf{1 0 0 \%}$ fertilization rate gave the highest costs of wheat cultivation (9524.00 £.fed ${ }^{-1}$ ) followed by UF with (8852 $£_{\text {.fed }}^{-1}$ ) and SCU with $\left(8320 £ . \mathrm{fed}^{-1}\right)$ at the same rate of application. The cost of wheat cultivation increased by increasing rate of applied nitrogen where CCU using at $150 \%$ fertilization rate achieved the highest cultivation cost (11036 $\left.\mathrm{E.fed}^{-1}\right)$ in the wheat season. It's clear that coated urea showed more costs of cultivation than that of un coated urea and this may be due to high price of coating and production. SCU is the lowest cost of wheat cultivation comparing with other coated urea where sulfur is the cheapest coating.

In case of maize conventional urea (CU) using at $100 \%$ fertilization rate recorded the highest cost of cultivation
(7875 ..fed $^{-1}$ ) comparing with the other treatments.

The maximum gross return of wheat crop as well as maize increase by increasing nitrogen rate, SCU at $100 \%$ fertilization rate gave the highest gross income of wheat (19840 $\left.\mathrm{E.fed}^{-1}\right)$ comparing with UF, $\mathrm{CCU}$ and $\mathrm{CU}$ at the same rate. On the other hand residual of CCU using at $100 \%$ fertilization rate achieved the highest gross income of maize (18025 .fed $^{-1}$ ) in comparison with SCU (17552 £.fed $\left.{ }^{-1}\right)$, UF (16882 E.fed $^{-1}$ ). SRNFs i.e. SCU, UF and CCU at $100 \%$ fertilization rate application as well as their residual enhanced wheat and maize grain yield more than that of conventional urea (CU) at $100 \%$ fertilization rate.

The highest net return of 11520 and 10800 Ł.fed $^{-1}$ were obtained by SCU for wheat plant and CCU for maize plant, respectively at $\mathbf{1 0 0} \%$ fertilization rate. The lowest net return in both seasons were indicated by $\mathrm{CU}$ at $\mathbf{1 0 0 \%}$ fertilization rate with net return 9230 and $8929{£ . f e d^{-1}}^{-1}$ for wheat and maize, respectively.

Table 12: Economic criteria for the different treatments at the wheat - maize cropping sequence.

\begin{tabular}{|c|c|c|c|c|c|c|c|c|}
\hline \multirow{2}{*}{ Treatments } & \multicolumn{2}{|c|}{$\begin{array}{c}\text { Total costs } \\
\left(£ . \text { fed }^{-1}\right)\end{array}$} & $\begin{array}{r}\text { Gross income } \\
\left(£ . \text { fed }^{-1}\right)\end{array}$ & \multicolumn{2}{c|}{$\begin{array}{c}\text { Net return } \\
\left(\text { ffed }^{-1}\right)\end{array}$} & \multicolumn{2}{c|}{ BCR } \\
\cline { 2 - 9 } & Wheat & Maize & Wheat & Maize & Wheat & Maize & Wheat & Maize \\
\hline CU100\% (control) & 7310 & 7875 & 16540 & 16804 & 9230 & 8929 & 2.26 & 2.13 \\
\hline SCU100\% & 8320 & 7225 & 19840 & 17552 & 11520 & 10327 & 2.38 & 2.42 \\
\hline SCU125\% & 8787 & 7225 & 19960 & 17710 & 11173 & 10485 & 2.27 & 2.45 \\
\hline SCU150\% & 9244 & 7225 & 20200 & 17887 & 10956 & 10662 & 2.18 & 2.47 \\
\hline UF100\% & 8852 & 7225 & 18880 & 16882 & 10028 & 9657 & 2.13 & 2.33 \\
\hline UF125\% & 9437 & 7225 & 19120 & 17119 & 9683 & 9894 & 2.02 & 2.36 \\
\hline UF150\% & 10024 & 7225 & 19380 & 17375 & 9356 & 10150 & 1.93 & 2.40 \\
\hline CCU100\% & 9524 & 7225 & 17740 & 18025 & 8216 & 10800 & 1.86 & 2.49 \\
\hline CCU125\% & 10280 & 7225 & 17860 & 18163 & 7580 & 10938 & 1.73 & 2.51 \\
\hline CCU150\% & 11036 & 7225 & 18500 & 18301 & 7464 & 11076 & 1.67 & 2.53 \\
\hline
\end{tabular}


The highest BCR (2.38) in wheat was achieved by SCU at $100 \%$ fertilization rate and (2.49) in maize was obtained by residual of CCU using at $100 \%$ fertilization rate.

From the economical point of view, it's clear that SCU at $100 \%$ fertilization rate applied treatment for wheat and residual of CCU at $100 \%$ fertilization rate for maize recorded the highest net return as well as BCR and both could be a good alternative to $\mathrm{CU}$ for enhancing yield and farmer income.

\section{Conclusion:}

Slow release nitrogen fertilizers (SRNFs) were more effective in enhancing growth, yield and yield components of plants as well as reducing $\mathrm{N}$ losses through volatilization, leaching and decomposition. So, it can be concluded that using of SRNFs especially SCU with $100 \%$ recommended dose achieved the highest growth, yield and yield component of wheat plants. Also, it was recorded that the residual of SRNFs were higher than conventional urea and we concluded that residual with the lower addition rates of conventional urea recorded the highest values of growth, yield and yield component of maize in wheat-maize cropping system.

\section{REFERENCES}

Abdel Nour, A. R. N. and H. S. A. Fateh (2011). Influence of sowing date and nitrogen fertilization on yield and its components in some bread wheat genotypes. Egypt. J. Agric. Res., 89 (4): 1413-1433.

Abd El-Razek, U. A. and A. A. ElSheshtawy (2013). Response of some wheat varieties to bio and mineral nitrogen fertilizers. Asian Journal of Crop Science 5 (2): 200-208.

Abou-Zied, S. T., E. M. Abd El-Lateef, A. Hanem, S. M. M. Hozayn, M. S. M. El-
Ashry, L. A. Abd El-Latif and R. E. Essa (2014). Effect of Different Slow Release Nitrogen Fertilizer Forms on Yield and Chemical Constituents of Maize and Soybean. Middle East Journal of Agriculture Research, 3(3): 645-652.

Al-Kanani, T., A. F. Mackenzie and N. N. Barthakur (1991). Soil water and ammonia volatilization relationships with surface applied nitrogen fertilizer solutions. Soil Science Society of America Journal 55: 1761-1766.

Almodares, A., M. Jafarinia and M. R. Hadi (2009). The effects of nitrogen fertilizer on chemical compositions in corn and sweet sorghum. AmericanEurasian J. Agri. Environ. Sci., 6: 441446.

A.O.A.C. (Association of Official Analytical Chemist) (1990). "Official Method of Analysis".15th ed. Association of Official Analytical Chemists, Washington. D. C., USA.

A.O.A.C. (1995). Official Methods of Analysis 16th Ed, A.O.A.C. Benjamin ranklin Station, Washington, D. C., U. S. A. pp 490-510.

Bojović, B. and A. Marković (2009). Correlation between Nitrogen and chlorophyll content in wheat (Triticumaestivum L.) Kragujevac J. Sci. 31: 69-74.

Buresh, R. J., E. R. Austin and E. T. Craswell (1982). Analytical methods in N-15 research.Ferti. Res. (3): 37-62.

Chapman, H. D. and P. Pratt (1961)." Methods of Analysis for soils, Plants and Waters".Division of Agric. Sci. Univ. California., USA.

El-Ghamry, A. M., A. A. Mosa and O. H. Zheiry (2016). Effect of some controlled release nitrogen fertilizer (coated area) on growth, yield and nitrogen uptake of corn plants. J. Soil Sci. and Agric. Eng. Mansoura Univ., 7(8): 523-527. 
EL-Metwally, A. E., S. A. Safina, F. E. Abdalla and S. S. El-Sawy (2019). Maize Grain Yield and its Quality as Affected by Previous Crop, Nitrogen Rate and Nutrients Foliar Application. J. Plant Production, Mansoura Univ., 10 (8): 707- 714.

Gagnon, B., N. Ziadi and C. Grant (2012). Urea fertilizer forms affect grain corn yield and nitrogen use efficiency . Can. J.Soil.Sci. 92:341-351.

Galloway, J. N., F. J. Dentener, D. G. Capone, E. W. Boyer, R. W. Howarth, S. P. Seitzinger and D. M. Karl (2004). Nitrogen cycles: past, present, and future. Biogeochemistry, 70(2): 153226. https://doi.org/10.1007/s 10533004-0370-0.

Glibert, P. M., J. Harrison, C. Heil and S. Seitzinger (2006). Escalating worldwide use of urea: A globalchange contributing to coastal eutrophication. Biogeochemistry 77: 441-463.

Gomez, K. A. and A. A. Gomez (1984). "Statistical Procedures for Agricultural Research".2nd ed., International Rice Research Institute, College, Laguna, 680pp.

Haderlein, L., T. L. Jensen, R. E. Dowbenko and A. D. Blaylock (2011). Controlled release urea as a nitrogen source for spring wheat in Western Canada: yield, grain $\mathbf{N}$ content, and $\mathbf{N}$ use efficiency. Scientific World Journal1 Suppl 2:114-21. doi: 10.1100/tsw.2001.309.

Hamd Alla, W. A.; E. M. Shalaby; R. A. Dawood and A. A. Zohry (2015). Effect of Crop Sequence and Nitrogen Fertilization on Productivity of Wheat. Elixir Agriculture 88: 36215-36222.

Hassan, S. W., F. C. Oad, S. D. Tunio, A. W. Gandahi, M. H. Siddiqui, S. M. Oad and A. W. Jagirani (2010). Impact of nitrogen levels and application methods on agronomic, physiological and nutrient uptake traits of maize fodder. Pak. J. Bot. 42: 4095-4101.

Hassanein, M.S., G. A. Ahmed, M. N. Zaki, H. I. El-Alia and M.M. Tawfik (2013). Response of two wheat cultivars grown in newly cultivated lands to iron and slow release $\mathbf{N}$ fertilizers. Australian J. of Basic and applied Sci., 7(1): 498-505.

Hatifield, J. L. and T. B. Parkin (2014). Enhanced efficiency fertilizers: Effect on agronomic performance of corn in lowa. Agro. J., 106:771-780.

Jadon, P., R. Selladurai, S. S. Yadav, V. M. Munuswamy, M. Dotaniya, $S$. Kundu, A. K. Singh, J. Bhadouriya and S. Jamra (2018). Enhancing plant growth, yield and nitrogen use efficiency of maize through application of coated urea fertilizer. International Journal of Chemical Studies. 6(6): 2430-2437.

Jia, S., X. Wang, Y. Yang, K. Dai, C. Meng, Q. Zhao and $X$. Wu (2011). Fate of labeled urea-15N as basal and topdressing applications in an irrigated wheat-maize rotation system in North China Plain: I winter wheat. Nutrient Cycling in Agroecosystems, 90(3): 331-346.

Kenney, D. R. and D. W. Nelson (1982). Nitrogen-inorganic forms. P. 643-698. In A.L. Page (ed) Methods of soil analysis. Agron. 9, Part 2: Chemical and microbiological properties, 2nd ed., Am. Soc. Agron. Madison Wisc., USA.

Klute, A. (1986). Methods of Soil Analysis. Part-1: Physical and Mineralogical Methods (2nd) American Society of Agronomy, Madison, Wisconsin. U.S.A.

Krupnik, T. J., J. Six, J. K. Ladha, M. J. Paine and V. C. Kessel (2004). An assessment of fertilizer nitrogen recovery efficiency by grain crops. In "Agriculture and the Nitrogen Cycle: 
Assessing the Impacts of Fertilizer Use on Food Production and the Environment" (A. R. Mosier, J. K. Syers, and J. R. Freney, Eds.). SCOPE 65, Paris, France, pp. 193-207.

Ladha, J. K., H. Pathak, T. J. Krupnik, J. Six and v. C. Kessel (2005). Efficiency of fertilizer nitrogen in cereal production: retrospects and prospects. Advances in Agronomy, 87, 85-156.

https://doi.org/10.1016/S0065-

2113(05)87003-8.

Malakouti, H. J., A. Bazbordi, M. Lotfalahi, A. A. Shahabii, K. Slavoshi, R. Vakil, J. Ghadari, M. H. Keshavarz, M. Ghazemzadeh, R. Ghanberpouri, M. Dashadi, M. Babakari and M. Zaynalifard (2008). Comparison of complete and sulphur coated urea fertilizers with pre-plant urea in increasing grain yield and nitrogen use efficiency in wheat. Journal of Agricultural Science and Technology 10: 173-183.

Mello, T. F., S. Buzetti, M. C. Fillho, F. S. Galindo and L. M. Nogueira (2017). Residual effects of nitrogen fertilizer with polymer coated urea in a corn crop. Rev. Caatinga, Mossoro, 30(3): 586-594.

Mikkelsen, R.L., H. M. Williams and A. D. Behel (1994). Nitrogen leaching and plant uptake from controlled release fertilizers. Fert. Res. 37: 43-50.

Mishra, J., P. H. Mishra and I. P. Pandey (2001). Nitrogen and sulphur nutrition of wheat crop. I. Growth and yield. Ann. Plant Soil Res. 3: 84-88.

Mukhtar, T., A. Muhammad, H. Shahid, T. Muhammad and M. Khalid (2011). Effect of nitrogen and phosphorus fertilizers on growth of maize hybrids. J. Agric. Res., 2011, 49(3): 333-339.

Muller, O. H. (1974). Controlled Release Fertilizer. United States Patent, Appl.
No.: 512,090 , Continuation-in-part of Ser. No. 337,456.

Nasima, J., M.Y. Khanif, W. Y. Wan and K.A. dharejo (2010). Maize Response to Biodegradable Polymer and Urease Inhibitor Coated Urea. Int. J. Agric. Biol., 12: 773-776.

Nayek, S., I. H. Choudhury, N. Jaishee and S. Roy (2014). Spectrophotometric analysis of chlorophylls and carotenoids from commonly grown fern species by various extracting solvents. Res. Jour. of chem. Sciences, 4(9): 63-69.

Ning, T. Y., G. O. Shao, Z. J. Li, H. F. Han, Y. wang, S. Tian and S. Y Chi (2012). Effects of urea types and irrigation on crop uptake, soil residual, and loss of nitrogen on maize field on the north china plain. Plant Soil Environment, 58(1): 1-8.

Page, A. L., R. H. Miller and D. R. Keeney (1982). "Methods of Soil Analysis". Part-2: Chemical and Microbiological Properties. 2nded. Amer. Soc. Agro. Madison. Wisconsin. U. S. A.

Pereira, H. S. (2009). Ammonia volatilization of urea in the out-ofseason corn. Revista Brasileira de Ciência do Solo, Viçosa, 33(6): 16851694.

Salman, O. A. (1988). "Polymer Coating on Urea Prills to Reduce dissolution Rate", J. Agric. Food Chem., 36:616621.

Sartain, J.B., W. L. Hall, R. C. Littell and E. W. Hopwood (2004). Development of methodologies for characterization of slow-released fertilizers Soil Crop Sci. Soc. Florida Proc. 637275.

Shavive, A. and R. L. Mikkelsen (1993). Controlled release fertilizers to increase efficiency of nutrient use and minimize environmental degradation, a review II, Fertilizer Research. 35: 112. 
Shehzad, M. A., M. Maqsood, M. A. Bhatti, W. Ahmadand M. R. Shahid (2012). Effects of nitrogen fertilization rate and harvest time on maize (Zea mays L.) fodder yield and its quality attributes. Asian J. Pharm Bio. Res 2 (1): 19-26.

Shiva, Y. Y. S., V. Pooniya, R. Prasad, M. Paland and R. Bansa (2016). Sulphurcoated Urea as a Source of Sulphur and an Enhanced Efficiency of Nitrogen Fertilizer for Spring Wheat Cereal Research Communications 44(3): 513-523.

Signor, M. and G. Barbiani (2013). Slow release or controlled release fertilizer: target results of four years of trials on maize. Notiziario Ersa, 1: 38-42.

Snedecor, G.W. and W.G. Cochran (1980). Statistical Methods. $7^{\text {th }}$ ed. Iowa State Univ. Press, lowa, USA.

Trenkel, M. E. (2010). Slow- and Controlled-Release and Stabilized
Fertilizers: An Option for Enhancing Nutrient Use Efficiency in Agriculture. International Fertilizer Industry Association (IFA), Paris, France.

Vashishtha, M., P. Dongara and D. Singh (2010). "Improvement in properties of urea by phosphogypsum coating" Int. J. Chemt. Rese., 2: 36- 44. Virta

Watson C. (2013). Slow and controlled release and stabilized fertilizers: a growing market. New Ag Int 9:33-35.

Wilson, M. L., C. J. Rosen and J. F. Moncrief (2009). A comparison of techniques for determining nitrogen release from polymer-coated urea in the field. Hort Science. 44: 492-494.

Zaman, M., M. L. Ngujen and B. F. Blennerharsettquin (2008). Reducing NH3, NO2 and NO3-N losses from a pasture soil with urease or nitrification inhibitors and elemental- S- amended nitrogenous fertilizers. Biol. Fertil Soils 44: 693-705. 


\section{تقنين إستخدام الأسمدة الآزوتية ذات الكفاءة المحسنة لتحسين إنتاجية محصولى القـح والذرة فى تعاقب محصولى تحت ظروف الأراضى الطينية}

إيمان حمدي عبد العزيز، ريهام محمد نجيب فياض، إيناس السعيد يوسف

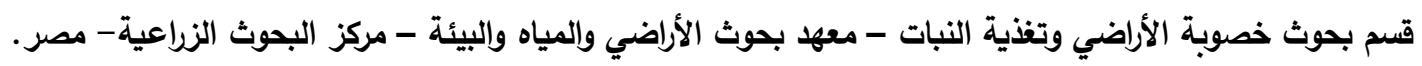
الملخص العربى

تستدعى التحديات الراهنة الي تطوير تكنولوجيات تصنيع الاسمدة و زيادة التوجه لاستذدام الاسمدة ذات الكفاءة المحسنة

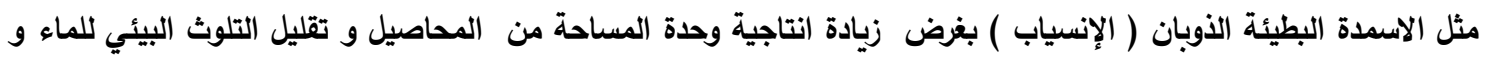

الهواء و التربة.

لذلك أجريت تجربتان حقليتان فى محطة البحوث الزراعية بتاج العز بمحافظة الاقهلية فى وسط دلتا نهر النيل - مركز

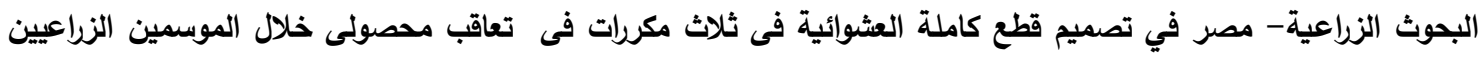

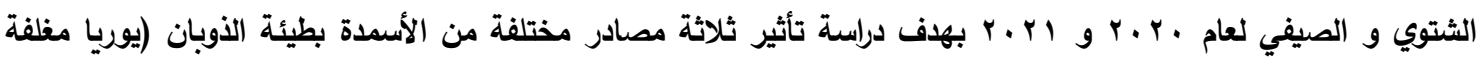

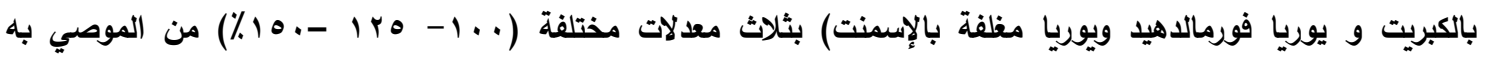

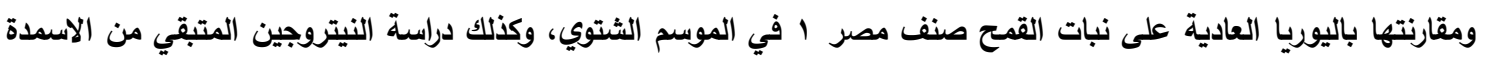

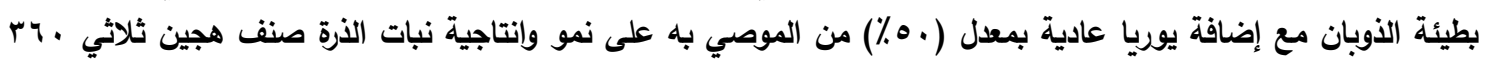

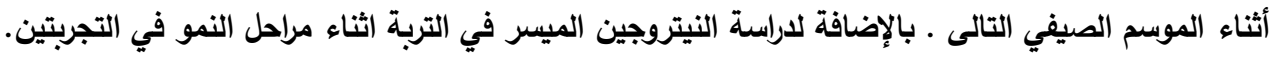

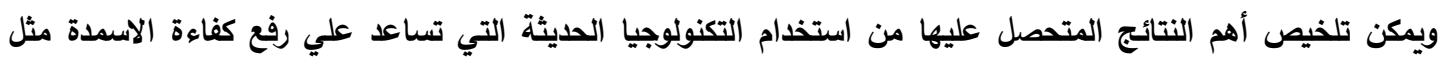

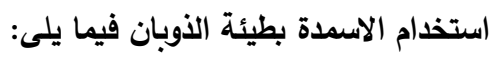

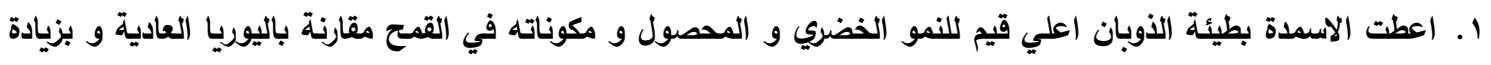
معدل النيتروجين تزداد قيم الصفات محل الدراسة.

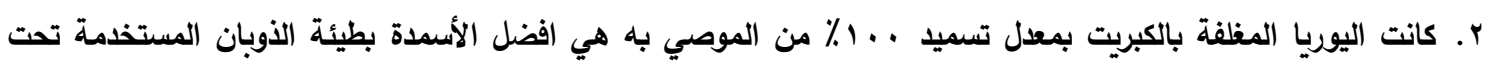

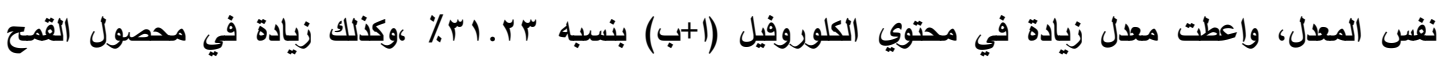

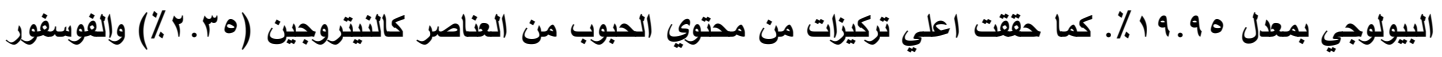

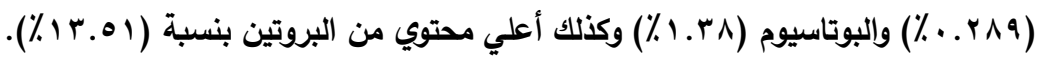

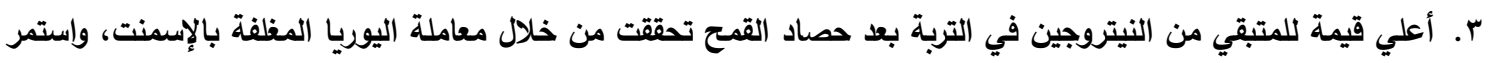
بنفس الاتجاه حتي بعد حصاد الذرة.

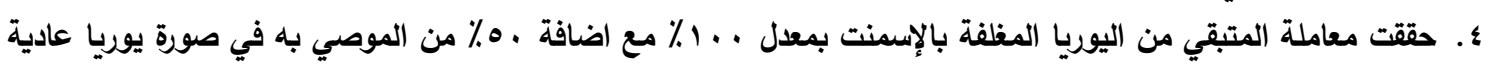

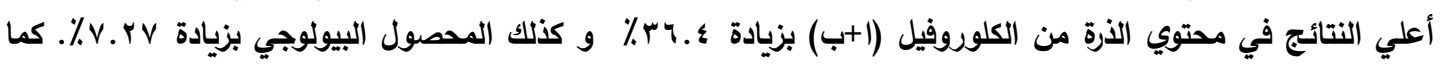

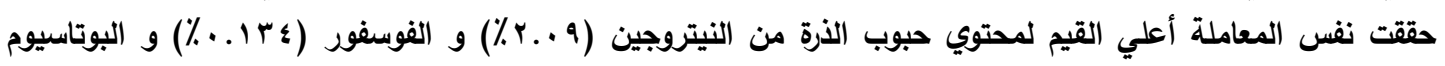

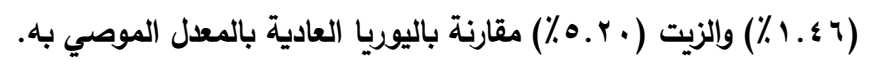

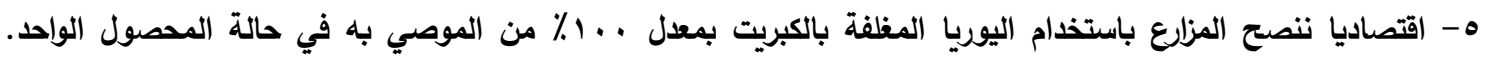

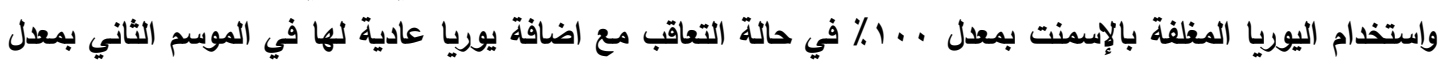

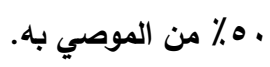

أسماء السادة المحكمين العصي به

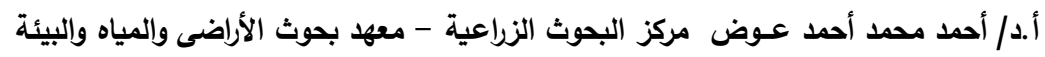

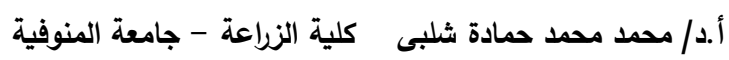

